Dina Helmy Ahmed Shalaby

\title{
The Struggle of Post colonialism's Transnational Nativity: Love As a Password to Cross Fictional Doors Into Centre or Periphery In Mohsin Hamid`s Exit West
}

\author{
By \\ Dina Helmy Ahmed Shalaby \\ Lecturer of English literature and criticism \\ Faculty of Arts, Menoufiya University
}

\begin{abstract}
This study examines transnational nativity as one of the most essential terms of the postcolonial theory. It deals with the consequent steps of the struggle which the immigrants, who belong to either the West or the East, have to pass through in order to become transnational natives in any host society. Weakening their authenticity without completely uprooting themselves from their original culture, is the first step which the immigrants should pass through in their new host society. The next step requires a real dwelling in the beyond of the immigrants` motherlands which could be either the West or the East. Such an act imposes an inevitable conflict with the other, who the immigrants need to communicate with. That is why the immigrants attempt to pursue the affinities with the other. In other words they need to hold negotiation with the natives of the host society. In Exit West by Mohsin Hamid, the major characters Nadia and Saeed depart their home, the unknown city through ordinary room doors which turn to be fictional because they have transferred them to far away countries. Nadia and Saeed pass through these doors to Mykonos island then London and finally Marin. In their long journey, they pass through the previous steps of transnational nativity. They could only put an end to their conflict with the others by pursuing the affinities with them at Marin. In this city love relationships which they have with others conquer the sense of antagonism between the different races. Nadia and Saeed make love the password which settles the issue of transnational nativity in the First world. In a similar vein, the Third and First worlds become homes for Hamid's diverse minor characters who pass from other fictional doors and fulfill transnational nativity stages of struggle. While Hamid puts a successful end to the protagonists`struggle, he lets some of his minor characters' struggle goes on without giving a satisfying end. Also, he uses other minor characters to portray man`s fear from, or denial of transnational nativity in the East or in the West.
\end{abstract}

Key Words: Transnational nativity- Beyond- Fictional doors-password-love. 
The Struggle of Post colonialism's Transnational Nativity: Love As a Password to

\section{Cross Fictional Doors Into Centre or Periphery In Mohsin Hamid's Exit West}

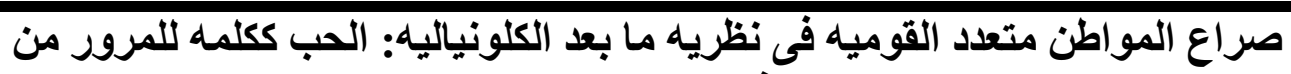

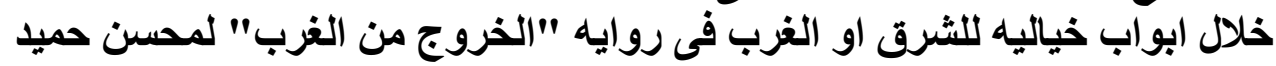

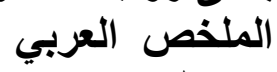

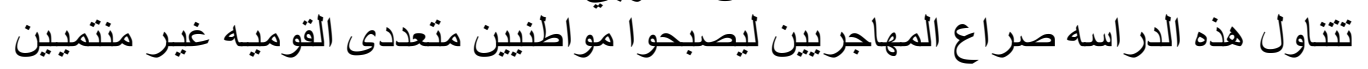

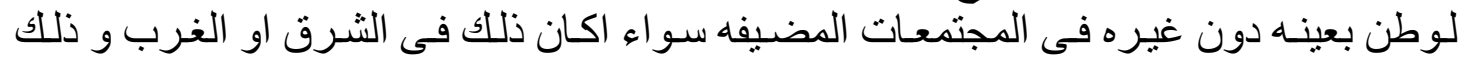

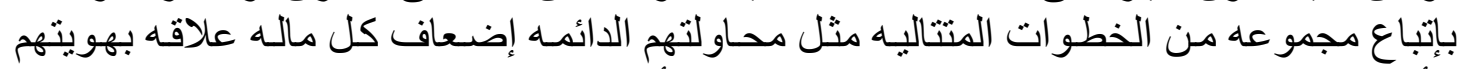

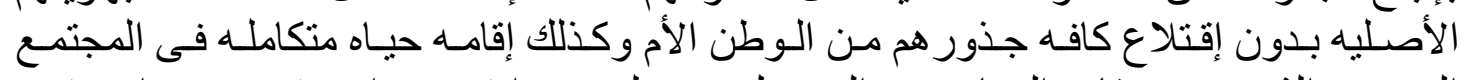

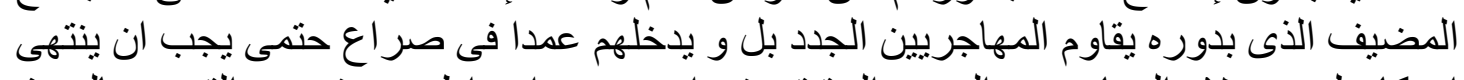

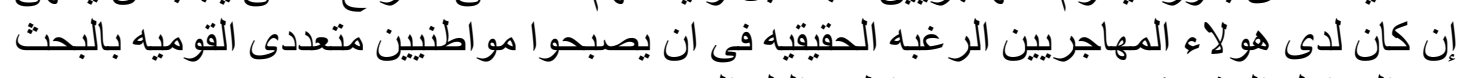

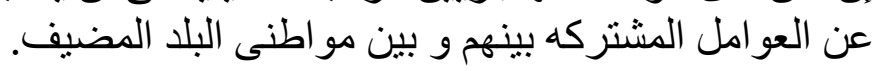

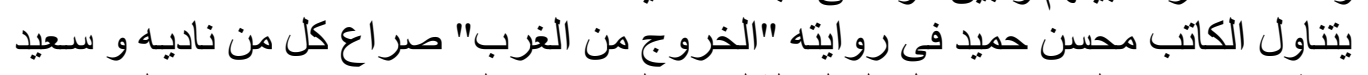

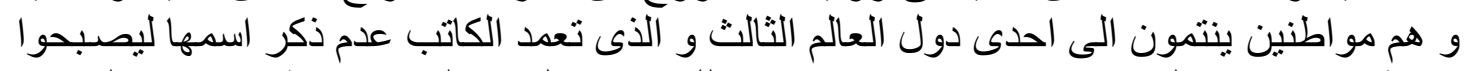

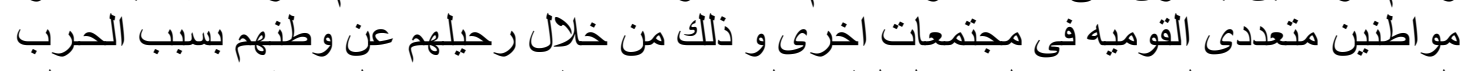

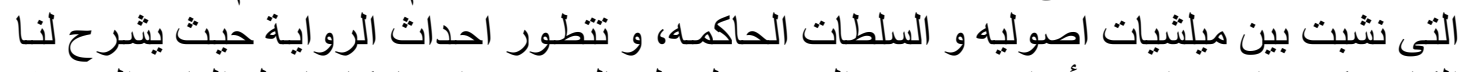

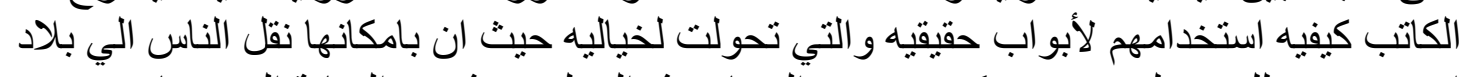

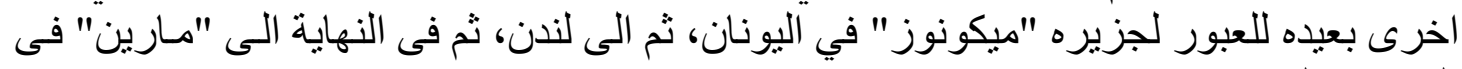

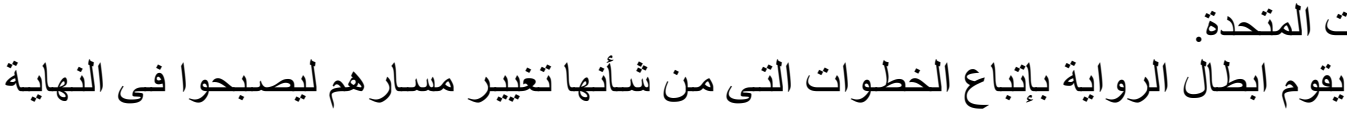

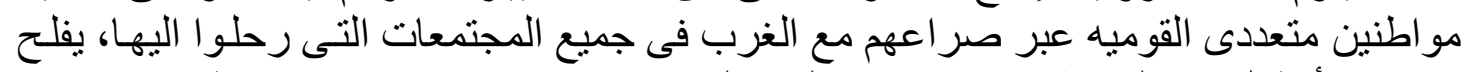

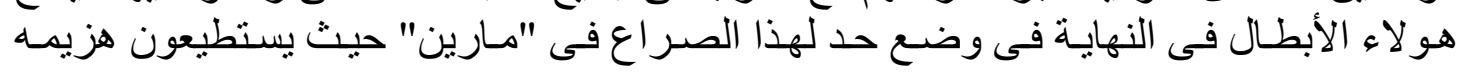

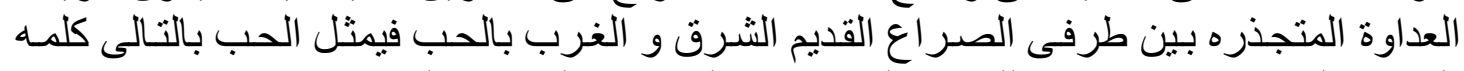

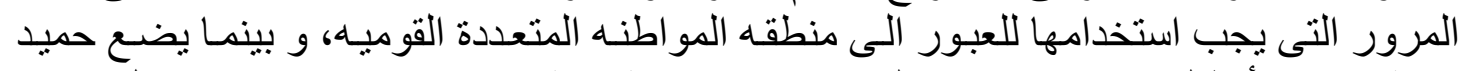

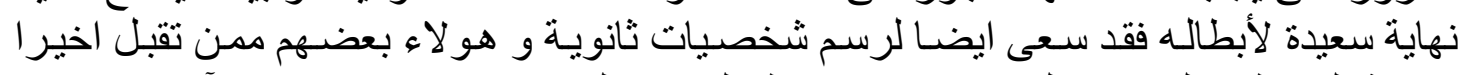

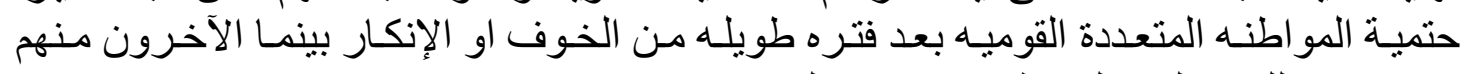
يصار عون للفوز بلقب المو اطنين متعددى القوميه. 


\section{Dina Helmy Ahmed Shalaby}

The immigrants who successfully struggle to become transnational natives, either in what post colonialism dictionary calls periphery (East) or centre (West) host societies, are described as people who have homes or "centres everywhere" (Hall Thinking the Diaspora 551), and simultaneously belong to "nowhere" (Iyer 277). Moreover, they are the people who have the potential capability to "forge and sustain multistandard social relations [which] link together their societies of origin and settlement" (Basch, Shriller, and Blanc 7), and make their "home and host societies a single arena of social action" (Foner 355). Thus, the transnational natives` home can be described as a "simultaneous" (Conrey 6) "very broad front" (Hall Thinking the Diaspora 557) and a "larger structure of belonging" (Conrey 7).

Wherever the immigrants come from, they have to follow some steps so that their turn to be transnational natives becomes more flexible. They have first to be convinced that: "the weaker the roots in a single territory, the stronger is the claim to the transnational" (Hear 250). Such conviction enables them to "weaken their purity, or the influence of their nation state" (Rowe 35), and become: "irrespective of their own migrant histories or 'ethnic' identities" (Jackson, Crang and Dwyer 2). Then the immigrants have to adopt an "antinostalgic mappings of homelands" (Conrey 29) "without assuming [their home`s] demise" (Faist, and Fauser 11) which they "recognize [its] continuing power" (Jackson, Crang and Dwyer 5). That clinging to the home explains why the transnational natives "remain socially, politically, culturally, and often economically part of the nation-state of their ancestors" (Basch, Shriller, and Blanc 8). In other words they remain committed to their "local identification" (Guarnizo, and Smith 15).

Moreover, the immigrants should "dwell in the beyond" (Bhabha 7), "beyond the reach of tribe, sect, or nation" (Seyhan 28-9), "beyond feelings of national belonging" (Valenzuela 183) which could "intrude or not to be asserted dialectically" (Miyoshi 94). That oppositional attitude which fluctuates between committing to home, and dwelling beyond it, makes the immigrants enter a real battleground where there is a struggle between "contesting and conflicting ideologies" (Seyhan 28) or different "disputing domains" (Giles 47). In fact, "Transnationality is constituted through the dialectical relations of the grounded and flighty, the settled and the flowing, the sticky and the smooth" (Jackson, Crang and Dwyer 8 ), and it is a reaction to the "tension between the strange and the familiar, the Other and the self" (Garrett 97).

Though conflict is an inescapable step of the turning of the immigrants to transnational nativity, it must stop. Thus the immigrants must begin "not to hold opposing notions too precious" (Garrett 97). 
The Struggle of Post colonialism's Transnational Nativity: Love As a Password to

Cross Fictional Doors Into Centre or Periphery In Mohsin Hamid's Exit West

Instead, they should pursue the "cultural affinities" (Valenzuela 183), and the "things that are shared" (Appiah 97) between them and the others. In a word they should look for a zone of "relationality and coalition" (Lim 196) between them and the others.

In Exit West, Mohsin Hamid brilliantly presents through his protagonists Nadia and Saeed, the tormenting journey of the immigrants who leave their homes and move to another. Strangely the immigrants in this novel have not used the usual means of transportations which we know. Instead, they use Hamid`s fictional doors. These doors are normal doors which turn to be magical means of transportation that quickly carry the immigrants from one place to another. Once the immigrants pass, their suffering begins because they attempt to commit to their homes and to become part of the new lands which they move to. Although the immigrants are not embraced by most of the host communities which they move to but after exhausting struggles they become transnational natives who belong to several homes including their original land. Nadia and Saeed struggle in some fantastic way, to become transnational natives. Likewise other minor characters who belong to the East and the West as well begin their struggle and pass through these doors.

Before involving the reader in their struggle to become transnational natives, Mohsin Hamid weaves Nadia and Saeed`s relationship. Their relationship begins, and continues for some time though both are entirely different. Apparently they are not different at all because when Saeed first meets Nadia in the university class in the unknown city, Saeed has been portrayed as a man who has "a beard, not a full beard, more a studiously maintained stubble" (3). Nadia, as well appears like conservative women who always wears "flowing black robes" (3). When they talk to each other after Saeed decides one day to stop noticing her and to go to speak to her, it becomes clear that they are extremely different. Unlike Saeed who considers his being not regular sometimes in prayer, a shortcoming, Nadia does not pray. She, moreover rides a motorcycle and does not wear a black cloth over her head.

Although Saeed becomes sure in this day that Nadia is different from him, he finds himself unable to stop thinking of her in the following day. In that same day, another dark skinned man has begun his journey to become a transnational native in the centre. He leaves his unknown home, and emerges through a fictional door which appears to be a dark closet doorway of bed room, into a house in Surry Hills, at Sydney, Australia. His physical transportation is the first step in the dark skinned man`s 


\section{Dina Helmy Ahmed Shalaby}

struggle to become a transnational native. He Physically uproots himself from his home. This uprooting is extremely hard not only because it is his body which "pulls him against gravity"(8) but also because some part of his ethnicity needs to be weaken so that he can dwell in the beyond and bear the coming conflict with the other. It seems that this is really his intention. That is why he unlike the other immigrants who decide to remain in this house without dwelling in the beyond, instantly runs away from it.

While this man still attempt to become transnational native, Nadia and Saeed still attempt to know each other. In the following week of their first talk, and after the end of their class, Nadia agrees to meet Saeed for the first time in a cafeteria. They mainly speak about her conservative black robe which she explains to Saeed that it is only worn "So men don't fuck with her" (17). It seems that Nadia does not consider Saeed one of those men and that is why she, later, accepts his invitation to have dinner in a Chinese restaurant where they talk about their dreams of travelling abroad. Nadia invites Saeed later to her flat. Such an invitation has not been easy to accept because the unknown city`s customs do not allow a single man to get into a single woman`s flat without being related. By making a little trick, Nadia helps Saeed to get into her flat. In a bag which she drops from her balcony, Saeed finds Nadia`s flat keys, and a spare black robe of her. Saeed wears the black robe and disguises as a woman, and easily he could get into Nadia`s flat where they smoke a joint and enjoy their day.

While Nadia, and Saeed nicely enjoy their day, some Filipina teenager girls who emerge through a fictional door in Tokyo district of Shinjuku at midnight pass through a painful experience through their attempt to become transnational natives. They attempt to dwell beyond their nation by weakening their ethnicity but they have refused to remove all their cultural identity and that makes them insist on speaking Tagalog language ${ }^{1}$ and wearing the Filipina clothes. That thing makes them fall as a prey to a young Japanese man who could only see them as strangers who could pollute his familiar culture. Strangely this man himself is somehow a stranger though he has not migrated to another country. He wears a suit, has tattoos on his body, and drinks Whisky which comes from Ireland. In fact being blind to his not whole pure identity makes the Japanese man aligned to violence against those who he considers strangers. That is why when the Japanese young man`s eyes which are "sober, flat, and not eyes that attracted the eyes of others," (29) catch the Filipina teenager girls who emerge from disused door that has been opened into an alley beside a bar, he quickly fingers a metal in his pocket, and follows the girls. 
The Struggle of Post colonialism's Transnational Nativity: Love As a Password to

Cross Fictional Doors Into Centre or Periphery In Mohsin Hamid's Exit West

It seems to be a hard time for both the Filipina girls and for Saeed and Nadia who their meetings become rare due to the war which breaks out between the fundamentalist militia (who come from hills), and the government. These circumstances have not banned Nadia from inviting Saeed to have sex with her. Saeed`s conservatism allows him only to kiss Nadia and to delay having sex with her till they are married. While both lovers have been romantically busy in having their first kiss in the unknown city, an old man from San Diego, California, locality of La Jolla, who has a home by the sea (the Pacific Ocean), has been differently busy. His attention has been directed to observe the refugees who come out of the ocean while the navy officers who established a perimeter around the old man`s house receive them. These refugees are going to be transported later by gray planes to Coronado.

The old man realizes that he somehow resembles these refugees especially if they decide to be transnational natives. He attempts to find a password to solve his conflict with the other. It is love which makes this man reconcile with his kid brother who has not spoken with him for years for unknown reasons. If the immigrants succeed in using a similar password, they will have a simultaneous larger front everywhere and nowhere. They will be like the old man which his reconciling nature makes him unable to decide or to name one "single place"(50), or a friend or a kin to go to after watching the refugees.

It seems that the old man knows the password which others like Nadia and Saeed will fight to know it later. They first get all their savings so that they can leave their home which war turns to a waste land. Before this, Nadia attempts to have sex again with Saeed who holds back at the last moment and suggests that because of war Nadia should move in to live with his parents. Nadia considers this a proposal which she has not accepted or rejected. On the other side Saeed accepts what he sees as confusion of Nadia.

After proposing to Nadia, and while Saeed drives back to his parents` home, Mohsin Hamid`s camera moves to a rooftop flat of some neighbourhood in Nadia and Saeed`s unknown city where a brave native man holds a pistol and waits in darkness. Suddenly, another man emerges from a black door of a room in this flat. Then, the other man lays on the floor for he has a knock off Russian assault rifle by his side. When that man gathers his strength, and gets on his feet, the brave native man, suddenly pushes him out of his flat and waits to have others like this man who can be described as immigrants who will fail to be transnational natives. This failure is because they do not want to pursue the affinities 


\section{Dina Helmy Ahmed Shalaby}

with the others. They do not believe in the idea of belonging to very broad home. Instead they belong to one fundamentalist ideology which does not make them pursue the affinities with the others. On the contrary they avoid anything which could make a common ground between them and the natives. In other words they avoid love which could unite them with the others. That is why they leave their homes, join the militants in the unknown city and help in making "battles more ferocious, and less unequal, than what had come before" (68).

The fall of the unknown city becomes imminent because of these fundamentalist strangers who participate in killing the natives like Saeed s mother who has been killed by a stray heavy-caliber round which passes by her car. Nadia`s desire to console Saeed besides her need to feel safe are what drive her to move to the home of Saeed 's parents. Before moving to the new home, Nadia has not stopped staring at the doors of her flat because rumours have spread about how the normal doors of the rooms turn to be magical and fictional transporting doors which could take people to faraway places. At Saeed`s home, Nadia and Saeed attempt to find that special door that could help them to leave their home. That is why they first forge a marriage certificate so that they are not punished by the militants who forbid any single woman from accompanying a man who is not related to her. They, then follow a tip from a friend after dressing according to the militants rules (hair hidden for Nadia- and beard for Saeed), and head out on foot to meet an agent (a man who could facilitate their moving through a fictional door to somewhere else by money), in a burnt out shopping centre.

After speaking with the agent who they could not see his face for he speaks to them from behind, Nadia and Saeed have a deal with him. Also they pay him the money which he demands though they are not certain of being not deceived. Of course they do not know where the fictional door will take them. Likewise, the members of the Tamil family who cross a fictional door in their home and they do not know where the door takes them. They just intend to become transnational natives. The father, mother, daughter, and son of the Tamil family emerge from an interior service door to a door below glass towers filled with luxury apartments in "Jumeirah Beach Residence" in Dubai as the first security camera shows.

Another camera picks the transnational Tamil family who decide to be antinostalgic and to dwell beyond their home and that is why they leave the door and walk in the streets of Dubai. The children who become startled by the sound of expensive automobile engines and the high towers as another camera shows, are probably what make the Tamil family who seems from a coastal village and not from a city leave this place. It is true that the members of this family attempt to be irrespective 
to their roots but they do not as well assume a complete demise of their home. That is probably what makes them dwell on the beyond by pursuing the affinities with the other. Thus they decide to go to a place which resembles the place where they originally come from. They head towards the sea which gravitates them and where two different security vehicles stop the family who "hold hands and did not resist or scatter or run" (93). It seems that the Tamil family who are "strangers" now insist on facing the inevitable conflict with the "familiar" other and to have home everywhere and nowhere.

The destiny of the Tamil family is unknown exactly like the future of Nadia and Saeed who do not only have different beliefs concerning sex and marriage but they also have opposing attitudes concerning migration and home: "Saeed desperately thought he would leave it only temporarily, never once and for all. Nadia was possibly even more feverishly keen to depart, and [that was] exciting to her" (94). Whatever are their intentions from migration, they prepare themselves to leave their home. They have to wait for days till a handwritten note has been pushed by someone under Saeed`s apartment door. It appears to be a note from the agent which tells the place and time of meeting to depart through a fictional door to some unknown place. The father of Saeed refuses to leave because he is an old man and because he cannot leave the place where Saeed`s mother is buried. In fact Saeed`s father knows that Saeed is not alone in his journey and that what makes him feel that his son will be safe.

In a dentist's office, the agent summons Saeed and Nadia where he gestures with his head to a black door. Nadia steps through the door which she enters and "fights to exit it" (104) to emerge at Mykonos island in Greece like Saeed who follows her. In Mykonos, Nadia and Saeed inhabit in a camp of immigrants. In this camp, their different attitudes about home become more apparent. Nadia believes that home could be a very broad front. It could be simultaneously located in the unknown city, Mykonos and in any other country. That limitless connection enables her to dwell beyond her original home and to remain committed to her local identity as well. She, though takes Mykonos island as home, insists on wearing her black robe. On the other side Saeed has been hit by a "stronger impulse of nostalgia"(94). That is why though he shaves his beard in order to weaken his ethnicity, he is incapable of having a larger structure of belonging. In fact to become transnational native, Saeed has to do more than shaving his beard. 


\section{Dina Helmy Ahmed Shalaby}

Though being different, they both have been involved in a tormenting conflict with the West. Being originally from somewhere else and Third World natives make Saeed and Nadia carriers of contesting ideology and position them in a domain which is different from the West. They become the flighty and flowing "strangers" in opposition to the grounded, and settled "familiar" West. Therefore, the Western guards of the doors (uniformed men who secure the fictional doors in Mykonos) heavily guard "doors out" which are doors to richer destinations, and strictly ban anyone from passing through it. This is exactly what takes place when Saeed and Nadia hear rumors that there is a door to Germany but it is guarded by Western guards. Like many others in Mykonos, Nadia and Saeed run to that door but the guards ban them so they head back to the camp.

Like the guards in Mykonos, like the Western mob in Vienna where Hamid takes his readers. Being different from the immigrants especially the militants of the unknown city who make massacres in Vienna streets and shoot unarmed people, drives the mob to move against all immigrants. They intend to attack migrants gathered near the zoo. A young woman from Vienna knows the mob`s intention. She realizes that immigrants are not all militants, some of them are ordinary people who intend to become transnational natives by pursuing the affinities with the others and making Vienna another home in their larger structure of belonging. That is why the young woman leaves her contemporary art gallery. She plans to join a human cordon to separate the two sides. The young woman gets into the train where she finds herself surrounded by her natives who "are angry, furious, and staring at her and at her badge with undisguised hostility" (110). The furious mob shout at the young woman, push her, and shove her off the train before reaching the zoo station. At this moment, she insists on walking on foot in the direction of the zoo.

A similar stubborn insistence is echoed in Mykonos where Nadia and Saeed attempt to pass through another "door out" which they find by coincidence. Unfortunately they fail to enter through this door and some guards follow them. In Nadia`s attempt to run away from those guards, she slips and her arm has been cut on the rocks. That makes Nadia in need for medical caring which she receives in a clinic at the outskirts of the old city in Mykonos which is a place that the immigrants are not allowed to pass.

Nadia`s cut is what allows her to pass. In that clinic, Nadia is temporally able to end the tension held between the disputing domains (EastlWest). Such thing takes place when Nadia strangely falls in love with a local volunteer teenager girl who has cleaned Nadia`s wound. The 
two women feel "there was a connection between them" (117), and this is why Nadia insists on visiting this girl daily. It is not a hard to solve this puzzle, Nadia has simply succeeded in pursuing the affinities between her and the other. It appears that love is the password because it is a shared feeling by all of humanity. It is what makes this girl help Saeed and Nadia who is not totally sure from her strange relationship with that girl, to find another way off Mykonos. The girl leads Nadia and Saeed one day to a guarded house, and before passing through the door in that house, the girl has given Nadia a warm hug which "lasted a long time" (118), whispered something to her which Saeed never hears and then Nadia and Saeed pass through another fictional door.

They emerge in a luxurious bed room in a palace like house in London where Nadia and Saeed have finally their private bed room. They feel a sense of security which has lasted only for one night. Next night, Nadia who insists on wearing her black robe, Saeed, and other immigrants like them who occupy the luxurious house pass through a harsh conflict. It resembles the conflict which Saeed and Nadia confront in Mykonos. It is a conflict between the "strangers" immigrants and the "familiars" natives of the West. It seems that the luxurious house belongs to natives who when their housekeeper finds "strangers" in the house, calls the police. The Policemen come and ask everyone by bullhorns to exit. Though the immigrants become terrified, they refuse to leave, and some of them gather in the street, and bang spoons, and cooking pots forming a kind of strike against the police force which withdraws. That withdrawal has not continued for long time especially after the newspapers headlines deliberately incite the natives later to get into conflict with the others who have been viewed as strangers who intend to make "legal residents a minority, and native-born ones few" (129).

The natives are definitely going to be a minority in the centre not only because of the flows of the immigrants, but also because of the natives themselves who unexpectedly move from the centre to periphery. Mohsin Hamid takes us to see the happy life of an accountant in Kentish town ${ }^{2}$ who unlike people who migrate to London, he "ventures out of it" (129) into a periphery called Namibia. At one morning, the Kentish accountant discovers a secret door in his flat. Instead of thinking about his daughter who left him as well as his ex-girlfriend, or even calling the authorities to inform about the door, the accountant steps through the door, and passes.

The Kentish accountant emerges, then in Namibia where he succeeds to become an unusual transnational native. It seems that he 


\section{Dina Helmy Ahmed Shalaby}

could weaken his sublime ethnicity, end the conflict with the natives and dwell beyond his home in London. His ability to do this is due to his being able to pursue the affinities with the natives of Namibia. Maybe there he finds the love, the thing which his native daughter, and exgirlfriend could not share. That what makes him a happy person who though happy in his new home, he remains loyal to his origin which forms with Namibia a larger structure of belonging or one big home for this man. That is why he remains in contact with his family in London. His daughter receives a photo from him in Namibia, and a message which says that he would not be returning, and that they might join him if they choose through the door in his flat.

Unlike the Kentish accountant who likes to dwell beyond his home, Saeed "finds it stressful to be packed in[ one house] so tightly with people who spoke in tongues he did not understand" (132). At this moment Saeed thinks of leaving the luxurious house and moving to another house in London populated by immigrants who belong to the unknown city on Vicarage Gate ${ }^{3}$. It seems that till now Saeed fails in the first step of the transnational nativity. $\mathrm{He}$ is unable to become antinostalgic to his home. That is why he attempts to convince Nadia to leave the luxurious house. The people in the new house could not afford a separate room for Nadia and Saeed. Thus, Nadia who unlike Saeed likes to contact the Nigerian people who populate most of the luxurious house now, refuses. Further, she considers herself one of the Nigerians, and attends their council which they hold to discuss their affairs as immigrants.

The Violence of the English mob has begun and that is probably why Nadia aligns with the other immigrants. This alignment has not forbidden the violence against her and Saeed. They have been knocked down one night by extremist nativist mob who look to Nadia and Saeed as "strange, and violent tribe" (134) who should be killed. Luckily, this night, Nadia and Saeed have only some injuries but they survive while three other immigrants pass away. By using violence, it seems that the conflict between the familiar West and the stranger East now grows more furious. This is what the Western media declares because next day on the television, there have been talks about a major operation to reclaim Britain for its natives. The operation has already begun when suddenly the army tightens a cordon around zones such as the luxurious house and other places populated by the immigrants.

Maybe that horrible time is what makes Saeed and Nadia return to kiss each other after long time of breaking up without known reasons. They could also notice a fox in the garden of the luxurious house who they believe it resembles them. It is "a noble animal, though it was fond 
of rummaging in the trash" (140) like Nadia and Saeed who are noble people who belong to a home and only because they attempt to have a broader front, the natives of the host society treat them as strangers and only allow them like the fox, rummaging in the trash. The worst is that the natives could kill them through the military operation. That is why the daily appearance of the fox relives Nadia and Saeed because it means that "the fox had not disappeared and not being killed" (141).

It seems that Nadia, Saeed, and other immigrants decide to remain and that makes the last attempt of the Western authority to get rid of them fails. When the authority cuts off the electricity over the immigrants and literally divides London into "dark London" of strangers and "light London" of natives in order to make the immigrants leave, no body moves. Moreover the council of the luxurious house and other different houses of immigrants encourage the peaceful resistance of the Western authority. Maybe this is what makes the military operation suddenly stops and the British government decides instead to build around London new cities called "the London Halo" which are all bounded by perimeter fences. The government promises the immigrants who will inhabit the new cities a home on forty square meters of land and a connection to all utilities of modernity if they build their own dwellings which are delivered to their owners by a list of names. The government arranges this list according to the amount of labour carried out by each one.

Apparently Nadia and Saeed will become finally transnational natives by having a new home beside their original. Likewise is the young woman from Tijuana ${ }^{4}$ who makes both her original home as well as America a very broad front. It seems that this woman succeeds in passing through some fictional door, weakening her ethnicity to some extent, and dwelling in the beyond after confronting the others and pursuing the affinities with them. That is why, after she has been labored in the United States, she returns to Tijuana to take her daughter. As a matter of fact, the mobile phones and the computers help this woman to remain in contact with her origin and not completely to take off her skin. They help her to contact her daughter who she has left earlier in an orphanage in Tijuana before passing through the fictional door. They make the young woman who emerges from a fictional door in the orphanage "recognize [her daughter] because she had seen her on the screens of phones and computers" (160-1). Maybe this flexibility and easiness in having a broader structure of belonging which does not impose deadly demolishing of the roots is what makes the daughter herself decide to leave Tijuana 


\section{Dina Helmy Ahmed Shalaby}

with her young mother through the same fictional door which the young mother has passed through.

While this mother and her daughter hope for a new life as transnational natives in a centre, an elderly man hopes for a similar new life in a periphery. This man used to sit on the balcony of his flat in front of the courtyard at Prinsengracht in the centre of Amsterdam and notices the foreigners who come from the common shed in this courtyard. The elderly man could not bear, at the beginning the idea of having strangers as transnational natives in his home. That is why when a "stranger" wrinkled old man who comes out from the shed attempts to contact him by elegantly doffing his hat to the elderly man, the elderly man looks at him with a degree of disdain. It seems that this stranger succeeds in becoming irrespective to some part of his past and that is why he attempts to contact the elderly man. On the contrary the elderly man`s behavior shows his incapability to remove some part of his ethnicity. This scene shows the expected conflict between the contesting ideologies of the centre and the periphery which is as an inevitable step of transnational nativity. Fortunately, this step lasts only for one day. Next day when the wrinkled old man repeatedly doffs his hat, the elderly man raises a glass of wine and makes a well-mannered nod of his head. This nod allows the elderly man in the third day to ask the wrinkled old man to join him in his balcony where they speak together although the wrinkled old man could not speak Dutch. In fact "they cobbled together a conversation with many gaps, but these gaps were eminently comfortable" (175).

The wrinkled old man as it seems succeeds to some extent in pursuing the things which are shared between him and the others and in having a broader front. In other words he succeeds in becoming a transnational native. On the other side the elderly man attempts to succeed in having as well a bigger home and becoming transnational native. That what makes the elderly man accept the wrinkled old man`s invitation to company him to his original home which is a periphery. Both pass through the door of the shed and emerge in the wrinkled old man`s studio at the hilly neighbourhood of Santa Teresa, in Rio de Janeiro. There, the wrinkled old man shows the elderly man his talented paintings and gifts him one of them intending to hold a romantic relationship with the elderly man. In fact he succeeds because a week later the two men have their first kiss in the flat in front of court yard. The elderly man is able finally to pursue the affinities with the other. Love is the password. It is what creates the simultaneous larger structure of belonging for him and also for the wrinkled old man. In other words love is what makes the wrinkled old man a transnational native in the centre, and the elderly man a transnational native in the periphery. 
While the old lovers find the password of transnational nativity, other people like Nadia and Saeed still look for it. Nadia becomes sure that she has lost a chance of having this password when she leaves the girl of Mykonos who she never forgets. One night Nadia has dreamed of this girl and wakes up then to find herself strangely "almost panting, and felt her body alive, or alarmed, regardless changed" (171). This change alongside with her mutual cold relationship with Saeed who becomes totally cold after he knows from a relative that his father has passed away, are what make her convince Saeed to abandon their position on the waiting list and to find a way out of London. Nadia and Saeed then find a door and pass to Marin, on the Pacific ocean (close to San Francisco) where Nadia and Saeed inhabit a shanty and find jobs. Nadia works at a food cooperative and Saeed joins a preacher (a man from Africa who runs a small organization which feeds, and affords shelter for the preacher's congregants) in his charitable mission.

Through the company of Saeed to this man, Saeed falls in love with his daughter who he sees for the first time in a ceremony which turns to be a remembrance of her mother. It appears later that the mother of this girl belongs to the unknown city of Saeed. In fact this girl is a transnational native who has a broader front. She takes Marin as her home although she is loyal to her ancestor's culture. That is why her "curly hair [is] tied up high on her head with a cloth" (199).

Her being a transnational native who remains to some extent committed to her original identity is probably what makes Saeed falls in love with her and flexibly pass the steps of transnational nativity including the last step which is pursuing the affinities with the others. Saeed`s loves to her makes him a different person. It is this love which makes him for the first time realize that his sorrow which follows the death of his parents resembles people's sorrow on death in all the world. It "unites" humanity for it is a "shared" experience (203) by all of the people who as well have the "potential for building a better world" (203).

By realizing that all the human beings on the globe share similar experiences, Saeed finally and after terrible conflicts in Mykonos and London is able to get rid of his restricting and traumatic nostalgia to home. Instead, he who lets his beard grow again, weakens his ethnicity, dwells beyond his home, and accepts having a larger structure of belonging. He accepts to make Marin another home for him. In a word he finally becomes a transnational native.

Saeed's being late in becoming antinotalgic and having his new transnational identity makes him resemble the old woman from the town 


\section{Dina Helmy Ahmed Shalaby}

of Palo Alto in California. This woman owns a house where she has lived her entire life. That is why the old woman refuses to sell her house which her children who get married to foreigners and have children who are not pure pester her to sell. Probably the different features of her granddaughter who has "features of the old woman, and yet looked mostly more, Chinese" (208) and who visited her for the first time are what change the old woman's mind. The love which this woman feels to her granddaughter is what makes her see her town which is now populated by "all sorts of strange people who looked more at home than she was" (209) differently. She is capable now to be irrespective to some part of her roots, dwell in the beyond and pursue the affinities with others as she has done with her granddaughter. She loves her and this is the password of the transnational nativity which the old woman has though she has never migrated.

Love is also the password which Nadia uses in order to become transnational native. That is why she friendly leaves the shanty for Saeed who has a new life and becomes just a friend to him. Nadia moves to live in the food cooperative. In this place she finds the password after having her final conflict. Again this conflict is because Nadia has not let all of her authentic identity demolishes. She preserves some part of it and that is why she continues to wear her black robe in Marin. That thing initiates a conflict between her and the native staff women in the food cooperative. This conflict has been passed before by Nadia in Mykonos and London. It is a conflict between the contesting ideologies of the East and the West. The colleagues of Nadia believe that Nadia`s robe makes her a "stranger" and that is why they avoid talking with her. Similarly a native pale skinned tattooed customer believes that Nadia`s robe makes her a "stranger" who should be excluded. That is why he intends to terrify and threaten Nadia by placing a pistol on the table in front of Nadia without shooting her. In return, the "stranger" Nadia remains silent without looking away while facing this man. That negative yet steady and courageous reaction of Nadia forces the tattooed man to leave taking his gun with him. Also, it forces her colleagues who become impressed by her solidity to talk with her though she wears a black robe.

For the first time Nadia "felt she was beginning to belong. Nadia`s contact with her colleagues makes her realize that "a door was opening up" (216) to enable her to finally dwell in the beyond, and to make a larger structure of belonging. This door has been completely opened up to Nadia by love which is the password of transnational nativity. Nadia realizes this fact and that is why when Nadia falls in love with a female head cook, she has never hesitated to go on in her bold relationship. Though being a prohibited relationship in her original home, Nadia has 
sex with the female head cook who plays the role of the man in their relationship: "the cook made love with a steady hand and a sure eye and a mouth that did little but it so very well" (219).

By this reconciling end of Nadia and Saeed`s love as well as their struggle to be transnational natives, Mohsin Hamid deliberately sends his final message to others who plan to pass through the fictional doors and struggle to become transnational natives. He advises them not to be afraid from passing from one home to another or from making a very broad front and a centre everywhere and nowhere. They should not be like the maid who lives in the hills in a palatial home outside Marrakesh. She could not imagine leaving her home unlike her husband who has left her, not long after marriage to Europe, and never returns, and her daughter who likewise passes through the doors but returns sometimes to visit her.

The maid fears only one step of the transnational nativity. She is afraid of the conflict with the other and its traumatic consequences of marginalization and ghettoization which might take place if she decides to have another home. She tells her daughter that in her home "she is at least known, and tolerated, and that is a blessing" (224) because this means that she is at least treated as a "human". Although she has true fears of the traumatic consequences of having other homes, she believes that one day she will pass through the doors as she tells her daughter.

When that day comes, the maid will enjoy her life exactly like Saeed, and Nadia who the new life of each one of them makes a lifetime pass without any contact between them. Half century later, Nadia has decided to cross the borders again back to her original home, the unknown city where the war has been ended. There she meets Saeed in a café. It seems that both of them who become transnational natives, succeed to preserve some part of their authentic identity. Saeed who becomes an old man still has a stubbly beard. Also, Nadia who becomes an old woman still wears her black robe. 


\section{Dina Helmy Ahmed Shalaby}

\section{Conclusion}

Immigrants who struggle to become transnational natives in the West, or the East are people who easily leave their homes, cross the borders, belong to nowhere, and everywhere, and have finally a very broad front. Their journey is a struggle which begins by the immigrants` adoption of an antinostalgic mapping of their homes beside dwelling in the beyond without completely slipping away from their ancestors cultures. Moreover, they should pursue the common ground or the affinities with the others. In Exit West by Mohsin Hamid, the major protagonists Nadia and Saeed who pass through diverse doors, succeed to struggle and become transnational natives, and to have multiple homes in centre and periphery. They commit themselves to the steps of transnational nativity which have been crowned eventually by love, the password, and the pursued affinity between people in all the world. Their life story marches with other minor characters who Hamid portrays their struggle to become transnational natives in the East and the West. 
The Struggle of Post colonialism's Transnational Nativity: Love As a Password to

Cross Fictional Doors Into Centre or Periphery In Mohsin Hamid's Exit West

\section{Bibliography}

Appiah, Kwame. Cosmopolitanism: Ethics in a World of Strangers. New York: W.W. Norton and Company, 2006. Print.

Ashcroft, Bill. Post-Colonial Transformation. London: Routledge, 2001. Print.

Basch, Linda, Nina Shriller, and Cristina Blanc. Nations Unbound: Transnational Projects, Postcolonial Predicaments, and Deterritorialized Nation-States. Australia: Gordon and Breach Publishers, 1994, Print.

Bhabha, Homi. The Location of Culture. London: Routledge,1994. Print.

Clifford, James. Routes: Travel and Translation in the Late Twentieth Century. Cambridge: Harvard University Press, 1997. Print.

Conrey, Carol. Contemporary Arab-American Literature: Transnational Reconfigurations of Citizenship and Belonging. New York: New York University Press, 2014. Print.

Dirlik, Arif. "LiteraturelIdentity: Transnationalism, Narrative and Representation". The Review of Education, Pedagogy and Cultural Studies.24-3 (2002). 209-234. http://www.tandfonline.com. 20 January 2018.

Faist, Thomas, and Margit Fauser. "The Migration Development Nexus: Toward a Transnational Perspective". The Migration-Development Nexus: A Transnational Perspective. Eds, Thomas Faist, Margit Fauser, and Peter Kivisto. UK: Palgrave Macmillan, 2011. Print.

Foner,Nancy. "What's New About Transnationalism? New York Immigrants Today and at the Turn of the Century". Diaspora: A Journal of Transnational Studies. 6-3 (1997). 355-375. http://muse.jhu.edu. 20 January 2018.

Garrett, Natasha. Transnationalism, Home, and Identity: Personal Essays. 2011. University of Pittsburgh. PhD Dissertation.www.thegigitalsilkroute.com. Print.

Giles, Paul. "Transnationalism and Classic American Literature." Transatlantic Literary Studies: A Reader. Eds, Susan Manning, and Andrew Taylor. Edinburgh: Edinburgh University Press, 2007. Print.

Guarnizo, Luis, and Michael Smith. "The Locations of Transnationalism". Transnationalism from Below. Eds, Michael Smith, and Luis Guarnizo.New Brunswick: Transaction Publishers, 1998. Print.

Gurnah, Abdulrazak. "Writing and Place". World Literature Today.78-2 (2004). (26-28).14 Oct 2017.Print.

Hall, Stuart. "Old and New Identities, Old and New Ethnicities". Culture, Globalization and World System: Contemporary Conditions for the Representation of Identity. Ed, Anthony D. King. Binghamton: State University of New York, 1991. 41-68. Print. 


\section{Dina Helmy Ahmed Shalaby}

Hall, Stuart. "Thinking the Diaspora: Home-Thoughts from Abroad". Postcolonialisms: an Anthology of Cultural Theory and Criticism. Eds, Gaurav Desai, and Supriya Nair. New Brunswick: Rutgers University Press, 2005. Print.

Hamid, Mohsin. Exit West. New York: Riverhead Books, 2017. Print.

Hear, Nicholas. New diasporas: the Mass Exodus, Dispersal and Regrouping of Migrant Communities. London: UCL Press, 1998. Print.

Iyer, Pico. The Global Soul: Jet Lag, Shopping Malls and the Search for Home. Great Britain: Bloomsbury, 2000. Print.

Jackson, Peter, Philip Crang, and Claire Dwyer."Introduction: the Spaces of Transnationality".Transnational Spaces. Eds, Peter Jackson, Philip Crang, and Claire Dwyer. London: Routledge, 2004. Print.

Lim,Eng-Beng. "The Epistemology of the Minor-Native in Transcolonial Border Zones". Performance in the Borderlands. Eds,Ramon H. Rivera, and Harvey Young.UK: Palgrave, 2011. Print.

Madrid, Alejandro. "Transnational Cultural Translations and the Meaning of Danzon across Borders".Performance in the Borderlands. Eds, Ramon H. Rivera, and Harvey Young.UK:Palgrave, 2011. Print.

Miyoshi, Masao. "A Borderless World? From Colonialism to Transnationalism and the Decline of the Nation-State". GlobaNLocal: Cultural Production and the Transnational Imaginary. Eds, Rob Wilson, and Wimal Dissanayake.Durham: Duke University Press,1996.Print.

Pieterse, Jan. "Globalization as Hybridization". Global Modernities. Eds, Featherstone, Mike, Scott Lash, and Roland Robertson. London: Sage Publication, 1995. Print.

Rowe, John. "Nineteenth-Century United States Literary Culture and Transnationality". Transatlantic Literary Studies: A Reader. Eds, Susan Manning, and Andrew Taylor. Edinburgh: Edinburgh University Press, 2007. Print.

Rushdie, Salman. Imaginary Homelands. London: Granta Books, 1991. Print.

Seyhan, Azade. Writing outside the Nation. New Jersey: Princeton University Press, 2001.

Valenzuela, Jose. "Transborder Dance: Choreographies by Minerva Tapia". Performance in the Borderlands. Eds,Ramon H. Rivera, and Harvey Young.UK: Palgrave, 2011. Print.

Vertovec, Steven. "Conceiving and Researching Transnationalism." Ethnic and Racial Studies.22-2 (1999). 1-25. http://www.tandfonline.com. 20 January 2018.

Vertovec, Steven. "Three meanings of 'diaspoa', exemplified among South Asian Religions." Diaspora: A Journal of Transnational Studies. 6-3 (1997).1-37. http://www.tandfonline.com. 20 January 2018. 